\title{
Effect of planting density on green ear yield of maize cultivars bred in different periods
}

\author{
Paulo Sérgio L e Silva ${ }^{1 *}$; Severino R Duarte ${ }^{1}$; Fábio Henrique T de Oliveira ${ }^{2}$; Júlio César do V Silva ${ }^{1}$ \\ ${ }^{1}$ Universidade Federal Rural do Semi-Árido (UFERSA), C. Postal 137, 59625-900 Mossoró-RN; ${ }^{2}$ UFPB, CCA, Av. Aprígio Veloso, 882, \\ Bodocongó, 58397-000 Campina Grande-PB; "CNPq Fellowship (corresponding author) paulosergio@ufersa.edu.br; fabio@cca.ufpb.br
}

\begin{abstract}
Corn cultivation in the Northeast region of Brazil is characterized by a great diversity of production systems, ranging from large companies (modern cultivars and relatively high planting densities) to small farms (family agriculture, traditional cultivars, and low planting densities). In the present work we evaluated the effects of planting density $\left(30 ; 40 ; 50 ; 60\right.$; or 70 thousand plants ha $\left.{ }^{-1}-\mathrm{TPH}\right)$ on green ear yield of cultivars Centralmex (traditional) and AG 510 (hybrid). Different densities were achieved by maintaining $1.0 \mathrm{~m}$ between rows and varying the spacing between pits, within the row. Cultivars and planting densities were combined in a factorial scheme, arranged in a random block design with four replicates and four $6 \mathrm{~m}$ long row plots. The number of green ears increased with density in both cultivars, but in a significantly more intense pace in cultivar AG 510. Cultivar AG-510 (14.9 t ha $^{-1}$ on average, maximum yield at $58 \mathrm{TPH}$ ) yielded significantly more unhusked green ears than cultivar Centralmex (13.6 tha-1 on average, maximum at $61 \mathrm{TPH}$ ). Marketable green ear yield increased with density in both cultivars, but more intensively in cultivar AG 510, which significantly out yielded cultivar Centralmex from $43 \mathrm{TPH}$ ahead. The difference between cultivars at the planting density of $70 \mathrm{TPH}$ was $14.4 \mathrm{t} \mathrm{ha}^{-1}$. There was no response of cultivar Centralmex in number of marketable husked green ears, while cultivar AG 510 increased yield with planting density. The difference between both cultivars started being significant at $38 \mathrm{TPH}$. Husked ear length decreased linearly and similarly in both cultivars as planting density increased. Planting density did not influence plant and ear height, and cultivar Centralmex was superior in both characteristics at all planting densities. There was no effect of cultivars on stalk diameter and root system biomass. Both characteristics decreased linearly as planting density increased.
\end{abstract}

Keywords: Zea mays, green corn, plant populations, plant height, root biomass.

\section{RESUMO}

Efeito da densidade de plantio sobre o rendimento de espigas verdes de cultivares de milho desenvolvidas em diferentes épocas

O cultivo do milho na região Nordeste do Brasil é caracterizado por uma grande diversidade de sistemas de produção, que variam de grandes empresas (cultivares modernas e densidades de plantio relativamente elevadas) a pequenas propriedades (agricultura familiar, cultivares tradicionais e baixas densidades de plantio). $\mathrm{O}$ objetivo do presente trabalho foi avaliar os efeitos da densidade de plantio $(30 ; 40 ; 50$; ou 70 mil plantas ha-1 - MPH) sobre o rendimento de espigas verdes das cultivares Centralmex (tradicional) e AG 510 (híbrido). As diferentes densidades foram obtidas mantendo-se 1,0 $\mathrm{m}$ entre fileiras e variando-se o espaçamento entre covas na fileira. As cultivares e densidades de plantio foram combinadas em um arranjo fatorial disposto no delineamento de blocos ao acaso, com quatro repetições e parcelas com quatro fileiras de $6,0 \mathrm{~m}$. O número de espigas verdes aumentou com a densidade nas duas cultivares, mas de maneira significativamente mais intensa na cultivar AG 510. A cultivar AG 510 (com rendimento médio de $14,9 \mathrm{t} \mathrm{ha}^{-1}$ e rendimento máximo na densidade de $58 \mathrm{MPH}$ ) produziu significativamente mais espigas verdes despalhadas que a cultivar Centralmex (rendimento médio de 13,6 t ha ${ }^{-1}$ e rendimento máximo na densidade de $61 \mathrm{MPH}$ ). $\mathrm{O}$ rendimento de espigas verdes comercializáveis aumentou com a densidade de plantio nas duas cultivares, mas mais intensamente na cultivar AG 510, que superou significativamente a cultivar Centralmex a partir da densidade de $43 \mathrm{MPH}$. A diferença entre cultivares na densidade de plantio de $70 \mathrm{MPH}$ foi $14,4 \mathrm{t} \mathrm{ha}^{-1}$. Não houve alteração significativa no número de espigas despalhadas comercializáveis na cultivar Centralmex. Porém, na cultivar AG 510, essa característica aumentou com a densidade de plantio. A diferença entre as cultivares tornou-se significativa a partir de $38 \mathrm{MPH}$. O comprimento da espiga despalhada diminuiu linearmente e de maneira similar em ambas as cultivares com o aumento da densidade de plantio. Adensidade de plantio não influenciou as alturas da planta e de inserção da espiga, com superioridade da cultivar Centralmex para essas características em todas as densidades de plantio. Não existiu efeito de cultivares sobre o diâmetro do colmo e biomassa do sistema radicular e ambas características diminuíram linearmente com o aumento da densidade de plantio.

Palavras-chave: Zea mays, milho verde, populações de plantas, altura de planta, biomassa do sistema radicular.

(Recebido para publicação em 28 de novembro de 2005; aceito em 19 de abril de 2007)

$\mathrm{I}_{m}^{\mathrm{n}}$ the Brazilian Northeast, corn (Zea mays L.) is grown for green ear production under dry land conditions or as an irrigated crop. The grains in the green ears are milky, having moisture content between 70 and $80 \%$. Green corn is a highly appreciated product by people in the Northeast, and is also used in the preparation of typical regional dishes. After the green ears are harvested, the husks are used as a feedstuff for cattle. The production of green ears is interesting for several reasons. The ears can be harvested in a very short time (70 to 75 days), and up to four annual crops can be obtained. If the grower does not intend to sell green ear corn, the dry grain can still be 
utilized. The crop almost does not present any disease or pest problems, and green ear, grain, and husk prices offer good compensation, especially during the off season.

One of the characteristics of corn cultivation in the region is the great diversity of production systems. One can find from large companies, which adopt modern cultivars and relatively high planting densities, to small farms, where the practice of family agriculture is the norm, with traditional cultivars grown at low planting densities. Therefore, interest exists in considering both types of cultivars in studies involving suitable cultural practices for corn. Higher planting densities increase plant sterility and the interval between male and female blooms, and reduce the number of grains per ear more dramatically in older cultivars than in more modern ones (Sangoi et al., 2002). Some publications (Sangoi et al., 2002; Widdicombe \& Thelen, 2002) have demonstrated the beneficial influence of higher planting densities on dry corn grain yield. With regard to green corn, few papers (Silva et al., 2002, 2003) have been found in the literature relating to this subject. These papers have shown that in common corn (Silva et al., 2003) or sweet corn (Silva et al., 2002), increases in green ear yield can be obtained by raising planting density.

Planting density studies are also interesting to corn researchers for at least two reasons. Adequate planting densities can contribute towards significant grain yield increases for farmers (Cardwell, 1992). Secondly, because corn yield response to density depends on genotypic (Chandra \& Gautan, 1997) and environmental influences (Bondavalli et al., 1970), and even negative responses of the crop to a given factor can be verified beyond certain limits.

The objective of the present work was to evaluate the effects of planting density on green ear yield and other characteristics of two corn cultivars, one representing traditional cultivars and, the other, modern cultivars.

\section{MATERIAL AND METHODS}

The research was carried out in an area of the experimental farm Rafael
Fernandes, located $20 \mathrm{~km}$ from the municipal seat of Mossoró, in the Brazilian Northeastern State of Rio Grande do Norte $\left(5^{\circ} 11^{\prime} \mathrm{S}\right.$ latitude, $37^{\circ}$ $20^{\prime} \mathrm{W}$ longitude, and $18 \mathrm{~m}$ elevation). The analysis of a soil sample from the experiment area, a Red Yellow Argisol (RYA), indicated: $\mathrm{pH}=6.8 ; \mathrm{Ca}=1.80$ cmol ${ }^{-1} \cdot \mathrm{dm}^{-3} ; \mathrm{Mg}=0.40 \mathrm{cmol} \mathrm{dm}^{-3} ; \mathrm{K}$ $=0.10 \mathrm{cmol}_{\mathrm{c}} \mathrm{dm}^{-3} ; \mathrm{Na}=0.01 \mathrm{cmol}_{\mathrm{c}} \mathrm{dm}^{-}$ 3; $\mathrm{Al}=0.00 \mathrm{cmol} \mathrm{dm}^{-3} ; \mathrm{P}=25 \mathrm{mg} \mathrm{dm}^{-3}$; Org. Matt. $=1.90 \mathrm{~g} \mathrm{~kg}^{-1}$. The soil was plowed by two harrowings, and was fertilized at sowing with $40 \mathrm{~kg} \mathrm{~N}$ (ammonium sulfate), $60 \mathrm{~kg} \mathrm{P}_{2} \mathrm{O}_{5}$ (single superphosphate), and $40 \mathrm{~kg} \mathrm{~K}_{2} \mathrm{O}$ (Potassium chloride) per hectare. Seeding was performed on July $15^{\text {th }}$, 1999, and four seeds pit $^{-1}$ were used. A replanting operation was performed six days after sowing to eliminate gaps of about $3 \%$. A thinning operation was performed 26 days after sowing, leaving the more vigorous plants in each pit.

Two cultivars (Centralmex and AG510) were submitted to densities of 30 ; 40; 50; 60; and 70 thousand plants $\mathrm{ha}^{-1}$. Cultivar Centralmex is an openpollinated variety, with yellowish semident grains, and tall late-producing plants. The original Centralmex is a cultivar with dent yellow grains and thick ears, in general showing 14 grain rows (Paterniani et al., 1977). Cultivar AG 510 is a modified triple hybrid with semi flint orange grains, and tall plants that produce earlier than Centralmex. The different densities mentioned were achieved by maintaining a constant spacing between rows $(1.0 \mathrm{~m})$ and varying the spacing between pits within the same row. Cultivars and plant populations were combined in a complete factorial scheme, arranged in a random block design with four replicates. Each plot consisted of four $6.0 \mathrm{~m}$ long rows. The useful area was considered as the space occupied by the two central rows, with the elimination of one pit at each end.

Pest control was performed by means of two deltamethrin sprays (5.0 $\mathrm{g} \mathrm{ha}^{-1}$ a.i.), at 23 and 29 days after sowing. Weed control was achieved by means of two hoeings, performed at 20 and 42 days after planting (DAP). Side dressing applications were performed at
28 and 44 DAP with $40 \mathrm{~kg} \mathrm{~N} \mathrm{ha-1}$ (ammonium sulfate). Harvest was performed in five steps, during the period from 75 to 85 DAP. Soil tillage was done with a tractor.

Green corn yield was evaluated by the number and total weight of green unhusked ears, and by the number and weight of both marketable unhusked and husked ears. Ears with a length equal to or above $22 \mathrm{~cm}$ and without signs of attack by pests were considered as marketable unhusked ears. Ears with a length equal to or above $17 \mathrm{~cm}$, displaying suitable grain set and health for selling purposes were considered marketable husked ears. After the green corn was harvested, the following characteristics were evaluated: plant and ear height, stalk diameter, fresh and dry matter weight of the above-ground part, root system dry matter weight, and marketable husked ear length. Except for green corn yield (usable plants in the plot), root system dry matter weight (plants of four pits), and ear length (all marketable husked ears), all other characteristics were estimated based on ten plants from the usable area of each plot. The distance from ground level to the insertion point of the highest leaf blade was considered as plant height. Ear height was considered as the distance from ground level to the first ear's insertion node. Stalk diameter was measured with a caliper rule below the ear insertion node. The same ten plants used to estimate plant height, ear height, and stalk diameter, were weighed to evaluate fresh matter weight. Next they were ground in a forage chopper, and after the ground material was homogenized, a $500 \mathrm{~g}$ sample was separated and taken to an oven until constant weight was achieved, in order to evaluate dry matter weight of the above-ground part. In order to evaluate root system dry matter weight, a $25-\mathrm{cm}$ deep cut was made in the soil, at each of the four sides of each sampled pit; plants were then pulled vertically. After being washed, roots were ground and taken to an oven until constant weight was achieved. Analysis of variance for the data was carried out using SAEG (SAEG, 1997), while a software by Jandel (1992) was used in the regression analysis. 
Table 1. Planting density effects on green ear yield and other characteristics of maize cultivars Centralmex (traditional) and AG 510 (modern) (Efeitos da densidade de plantio sobre o rendimento de espigas verdes e outras características das cultivares de milho Centralmex (tradicional) e AG 510 (moderna)). Mossoró, UFERSA, 1999.

\begin{tabular}{|c|c|c|c|}
\hline Characteristics $(y)$ & Cultivars & $\begin{array}{l}\text { Planting density effects } \\
\text { (d, i.e., } 30,40,50,60 \text {, and } 70 \text { thousand plants ha- }{ }^{-1} \text { ) }\end{array}$ & $\mathbf{R}^{2}$ \\
\hline Total no. of ears ha ${ }^{-1}$ & $\begin{array}{l}\text { Centralmex } \\
\text { AG } 510\end{array}$ & $\begin{array}{l}y=13,823 \cdot 9^{* *}+642.9^{* *} \\
y=9,189.2^{* *}+861.0^{* *} d\end{array}$ & $\begin{array}{l}97 \\
99\end{array}$ \\
\hline Total ear weight $\left(\mathrm{kg} \mathrm{ha}^{-1}\right)$ & $\begin{array}{l}\text { Centralmex } \\
\text { AG } 510\end{array}$ & $\begin{array}{l}y=3,912 \cdot 6^{* *}+361 \cdot 1^{* *} d-3 \cdot 1^{* *} d^{2} \\
y=-576 \cdot 3^{* *}+551 \cdot 2^{* *} d-4 \cdot 5^{* *} d^{2}\end{array}$ & $\begin{array}{l}93 \\
91\end{array}$ \\
\hline Number of marketable unhusked ears ha ${ }^{-1}$ & $\begin{array}{l}\text { Centralmex } \\
\text { AG } 510\end{array}$ & $\begin{array}{l}y=48,802.8^{* *}-15,831,000^{* *} d^{-2} \\
y=113,221.7^{* *}-445,844.7^{* *} d^{-0,5}\end{array}$ & $\begin{array}{l}98 \\
99\end{array}$ \\
\hline Weight of marketable unhusked ears $\left(\mathrm{kg} \mathrm{ha}^{-1}\right)$ & $\begin{array}{l}\text { Centralmex } \\
\text { AG } 510\end{array}$ & $\begin{array}{l}y=12,327 \\
y=-2,125 \cdot 7^{* *}+622 \cdot 4^{* *} d-5 \cdot 4^{* *} d^{2}\end{array}$ & 90 \\
\hline Number of marketable husked ears ha-1 & $\begin{array}{l}\text { Centralmex } \\
\text { AG } 510\end{array}$ & $\begin{array}{l}y=32,998 \\
y=52,514 \cdot 5^{* *}-19,245,000^{* *} d^{-2}\end{array}$ & 82 \\
\hline Weight of marketable husked ears $\left(\mathrm{kg} \mathrm{ha}^{-1}\right)$ & $\begin{array}{l}\text { Centralmex } \\
\text { AG } 510\end{array}$ & $\begin{array}{l}y=1,494.7^{* *}+233 \cdot 4^{* *} d-2 \cdot 3^{* *} d^{2} \\
y=-3,561 \cdot 0^{* *}+512 \cdot 9^{* *} d-4 \cdot 9^{* *} d^{2}\end{array}$ & $\begin{array}{l}80 \\
82\end{array}$ \\
\hline Husked ear length $(\mathrm{cm})$ & $\begin{array}{l}\text { Centralmex } \\
\text { AG } 510\end{array}$ & $y=21.12^{* *}-0.074^{* *} d$ & 99 \\
\hline Fresh biomass of the above-ground part ( $\left.\mathrm{kg} \mathrm{ha}^{-1}\right)$ & $\begin{array}{l}\text { Centralmex } \\
\text { AG } 510\end{array}$ & $\begin{array}{l}y=33,809 \cdot 9^{* *}-8,150,900^{* *} d^{-2} \\
y=25,413 \cdot 9^{* *}-8,148,800^{* *} d^{-2}\end{array}$ & $\begin{array}{l}78 \\
88\end{array}$ \\
\hline Dry biomass of the above-ground part $\left(\mathrm{kg} \mathrm{ha}^{-1}\right)$ & $\begin{array}{l}\text { Centralmex } \\
\text { AG } 510\end{array}$ & $\begin{array}{l}y=10,632.0^{* *}-2,500,900^{* *} d^{-2} \\
y=8,735.4^{* *}-3,110,900^{* *} d^{-2}\end{array}$ & $\begin{array}{l}78 \\
89\end{array}$ \\
\hline Plant height $(\mathrm{cm})$ & $\begin{array}{l}\text { Centralmex } \\
\text { AG } 510\end{array}$ & $\begin{array}{l}y=249 \\
y=180\end{array}$ & - \\
\hline Ear height $(\mathrm{cm})$ & $\begin{array}{l}\text { Centralmex } \\
\text { AG } 510\end{array}$ & $\begin{array}{l}y=147 \\
y=90\end{array}$ & $\begin{array}{l}- \\
-\end{array}$ \\
\hline Stalk diameter $(\mathrm{cm})$ & $\begin{array}{l}\text { Centralmex } \\
\text { AG } 510\end{array}$ & $y=2,025^{* *}-0.0085^{* *} d$ & 94 \\
\hline Dry biomass in root system (g pit $\left.{ }^{1}\right)$ & $\begin{array}{l}\text { Centralmex } \\
\text { AG } 510\end{array}$ & $y=80.87^{* *}-0.8273^{* *} d$ & 94 \\
\hline Number of tassel branches (no. tassel-1) & $\begin{array}{l}\text { Centralmex } \\
\text { AG } 510\end{array}$ & $\begin{array}{l}y=22.9^{* *}-0.0000099^{*} d^{3} \\
y=16.8^{* *}-0.0000083^{*} d^{3}\end{array}$ & $\begin{array}{l}78 \\
88\end{array}$ \\
\hline
\end{tabular}

$\mathrm{NS}=$ non-significant (não significativo); ${ }^{*}=$ Significant, $\mathrm{t}$ test, $\mathrm{p}<0.05$ (significativo, teste $\mathrm{t}, \mathrm{p}<0,05$ ); $* *=$ Significant, $\mathrm{t}$ test, $\mathrm{p}<0.01$ (significativo, teste $\mathrm{t}, \mathrm{p}<0,01$ ).

\section{RESULTS AND DISCUSSION}

There were effects of cultivars $(\mathrm{C})$, planting density (D), and of the C x D interaction on total number of green ears. Although the responses of both cultivars were linear and positive as planting density increased, yield increases were higher in cultivar AG 510 as planting density increased, which explains the interaction. Considering that the Tukey test value for testing cultivars was 4.04 at $5 \%$ probability, it can be deducted that cultivar AG-510 became superior to cultivar Centralmex starting at a density of approximately 40 thousand plants ha-1 (Table 1). The total number of green ears ha- ${ }^{-1}$ of cultivar Centralmex ranged 33,11 thousand (30 thousand plants $\mathrm{ha}^{-1}$ ) to 58,83 thousand (70 thousand plants $\mathrm{ha}^{-1}$ ). The corresponding values for cultivar
Centralmex were 35,02 and 69,46, respectively.

There was an effect of cultivars (C) and densities (D), but not of the C x D interaction on total weight of unhusked green ears (Table 1). Cultivar AG-510, which produced $14.9 \mathrm{t} \mathrm{ha}^{-1}$ on average, was superior to cultivar Centralmex $\left(13.6 \mathrm{t} \mathrm{ha}^{-1}\right)$. Although no interaction effect was verified, the maximum yield for both cultivars would be obtained at densities of 58 thousand and 61 thousand plants ha ${ }^{-1}$, respectively. Therefore, cultivar AG 510 supports slightly higher planting densities than the other cultivar, in relation to total green ear weight.

An effect of cultivars x planting densities interaction was verified on the number of marketable unhusked ears (Table 1). Both cultivars responded to increased planting densities. However, the exponents for $d$ indicate that increases in cultivar AG 510 were superior to increases in Centralmex, which explains why the interaction occurred. Cultivar AG-510 was superior to cultivar Centralmex at all planting densities tested. The difference at the planting density of 30 thousand plants ha $^{-1}$ was $651 \mathrm{~kg} \mathrm{ha}^{-1}$, while at the planting density of 70 thousand plants $\mathrm{ha}^{-1}$ the difference was $14,4 \mathrm{t} \mathrm{ha}^{-1}$, approximately. Despite this fact, the difference between both cultivars only became significant in the density of 43 thousand plants $\mathrm{ha}^{-1}$, approximately. This can be inferred from the equations presented (Table 1) and from the Tukey test value $\left(4,162 \mathrm{~kg} \mathrm{ha}^{-1}\right)$ in the comparison between cultivars.

An effect of the cultivars x planting densities interaction was also verified for marketable unhusked green ear weight (Table 1). In this case, cultivar Centralmex did not respond with higher 
yields to increased planting densities, while the response of the other cultivar was quadratic, with a maximum value at the density of 58 thousand plants ha 1. Cultivar AG 510 was superior to cultivar Centralmex at all planting densities, but this superiority was only significant between densities of approximately 40 thousand plants ha ${ }^{-1}$ and 75 thousand plants ha ${ }^{-1}$, at which the difference between yields in both cultivars was higher than the value calculated by Tukey test at 5\% probability $\left(1,797 \mathrm{~kg} \mathrm{ha}^{-1}\right)$.

Effects of cultivars (C), planting densities (D), and of the C x D interaction were observed for number of marketable husked green ears (Table 1). There was no response of cultivar Centralmex in relation to this trait, but cultivar AG 510 showed an increased yield as planting density increased. The difference between both cultivars became significant from 38 thousand plants ha-1 (with a Tukey test value of 6,275 plants $\mathrm{ha}^{-1}$ ), approximately.

There was an effect of cultivars and planting densities, but not of the C x D interaction on husked green ear weight (Table 1). Maximum yields in cultivars AG 510 and Centralmex would be obtained at densities of 52 thousand plants ha ${ }^{-1}$ and 51 thousand plants $\mathrm{ha}^{-1}$, respectively. Cultivar AG 510 was superior to the other cultivar at all planting densities (equations on Table 1) and by the Tukey test value $(1,274$ $\mathrm{kg} \mathrm{ha}^{-1}$ ).

The effects of planting density on the characteristics employed to evaluate green corn yield observed in this work were in agreement with those obtained by other authors (Silva et al., 2003).

Husked ear length decreased linearly and similarly in both cultivars as planting density increased (Table 1), in agreement with observations by other authors (Bavec \& Bavec, 2002). This decrease is important because some growers frequently wish to use higher planting densities in order to obtain greater forage yield, which attains high prices during the off season. In fact, increasing planting density also increased fresh and dry biomass of the above-ground part in a similar way in both cultivars (Table 1). However, because husked ear length decreased as a consequence of increased planting densities, the decision to produce more forage must be made cautiously, taking into account at least the relative price of green ears and husks. This is because green ear length is one of the most important characteristics in sales. It must be pointed out that the adjusted fresh and dry biomass equations (Table 1 ) indicate that the increases in these characteristics became progressively smaller as planting density increased. This tendency of reduction in biomass with planting density increase is in good agreement with results by other researchers (Maddoni \& Otegui, 2004). Fresh and dry biomass of the aboveground part were greater in cultivar Centralmex, i.e., in the more ancient cultivar.

Planting density did not influence plant height and ear height (Table 1). Cultivar Centralmex was superior to the other cultivar with regard to both characteristics, at all planting densities. Incidentally, this superiority of Centralmex with regard to plant height must have contributed to its fresh and dry biomass superiority in the aboveground part (Table 1). As a result of increased planting density, plant height in corn may remain unchanged (Bangarwa et al.; 1993) or may be influenced either positively (Merotto Junior et al.; 1997) or negatively (Silva et al.; 2003). The discrepancies in relation to planting density effects on plant height are certainly due to the different planting densities tested by different authors, among other environmental factors, but also resulted from the characteristics of the evaluated cultivars.

There was no effect of cultivars on stalk diameter and root system biomass (Table 1). Both characteristics decreased linearly as planting density increased. The number of tassel branches also decreased in both cultivars. The number of tassel branches in cultivar Centralmex was higher than in the other cultivar at all planting densities, but no interaction effect was observed.

The planting density effects were different, therefore, for the evaluated characteristics (Table 1). At the range of the studied densities, total green ear yield increased as planting density increased; however, in the case of marketable green ears, these increments were smaller or even absent (for some characteristics in cultivar Centralmex), or a yield decrease was verified after a maximum value was reached. Similar observations can be made for other plant characteristics.

The negative effects of increasing plant density (on stalk diameter and root system dry biomass) or from an optimal density (marketable unhusked ear weight and number and weight of marketable husked ears in cultivar AG 510) could be mainly due to a reduced availability of nutrients and light, since no competition for water was expected to occur due to the use of irrigation. However, other factors could be involved. Soil water content is higher in corn plots infested with weeds than in plots that are kept weed-free (Thomas \& Allison, 1975). This could be a suggestion that, in planting density studies, the negative effects of increased densities may not be caused only by water availability, but also by a reduced capacity of the root system in absorbing water. It also suggests that, even in irrigated crops, increased planting densities could reduce yields by reducing the root system's capacity to absorb water. As previously mentioned, the increase in planting density reduced the root system of both cultivars linearly (Table 1). Similar reasoning as suggested for water competition could be applied to competition for nutrients and light. In relation to light, the smaller yields observed at higher densities could be due to smaller photosynthetic rates, caused by mutual shading, but also by a smaller leaf area produced and/or by accelerated leaf senescence. An increased planting density increases light attenuation in the corn canopy (Borras et al., 2003), reduces leaf area index (LAI) (Bavec \& Bavec, 2002), and increases leaf senescence (Borrás et al., 2003). Last, it must be mentioned that an increased planting density influences the quality of the light that is received by the leaves. Due to the fact that absorption by green tissues is more intense at wavelengths corresponding to blue (400 
$-500 \mathrm{~nm})$ and red $(600-700 \mathrm{~nm})$, and that reflection is more intense at the nearred region $(700-800 \mathrm{~nm})$, the red:nearred ratio that reaches the base of the plant is reduced at high leaf area indices (Holmes \& Smith, 1977). Many species present an increase in leaf senescence under environments enriched with nearred radiation or with a low red:near-red ratio (Borras et al., 2003).

Among the six characteristics used to evaluate green corn yield, an interaction effect between cultivars $x$ planting densities occurred in four of them (Table 1). A superiority of cultivar AG 510, that is, of the cultivar considered more modern, was observed in relation to these four characteristics. The superiority of current cultivars in relation to older cultivars is attributed (Sangoi et al., 2002) to three groups of characteristics. First, a reduced allocation of dry matter to tassels, stimulating a more balanced allometric relation between male and female inflorescences. Second, a more compact architecture, represented by smaller plants and a greater number of erect leaves, favoring an increase in solar radiation interception. Third, a small ear height/plant height ratio, to promote higher resistance to lodging. As a matter of fact, in the present work, cultivar Centralmex, which is older and generally less productive, showed larger tassels than the other cultivar at all planting densities (Table 1). The competition effect for nutrients and carbohydrates between ear and tassel will be so much more severe as will the environment's adverse conditions (Magalhães et al., 1993), and this includes higher planting densities. In addition, large tassels cause leaf shading. In this work, leaf traits were not evaluated, but cultivar Centralmex also showed larger plants, which would be less desirable also under higher planting densities (Sangoi et al., 2002). It is possible that another factor, related to the genetic nature of the cultivars evaluated, is involved in the superiority of cultivar AG 510 in relation to cultivar Centralmex. Evidence exists that from the initial plantlet stages, corn plants have the ability to detect neighboring plantlets by means of red/near-red signals, and can change their dry matter allocation and morphology (Maddoni et al., 2002). This means that hierarchies are established early between plants, indicating a distinct ability to capture resources, originating from a differential capacity to detect neighboring plants. Within this context, dominant plants seem to have an improved perception of neighboring plants, which would help them develop shading-avoidance characteristics (as, for example, faster growth and a more convenient leaf orientation) sooner than dominated plants (Maddoni \& Otegui, 2004). Maybe this competition process between plants could be more intense in cultivar Centralmex (which is genetically less uniform, since it is a free-pollination cultivar) than in cultivar AG 510 (triple hybrid).

It can be therefore concluded that, in both cultivars, increased planting densities positively and similarly influenced fresh and dry biomass in the above-ground part of plants, as well as total weight and marketable husked ear weight. Increased planting densities had a negative effect on husked green ear length, stalk diameter, root system dry biomass, and number of tassel branches, but did not influence plant height and ear height. The cultivars had different behaviors as a response to increased planting densities, with regard to total number of ears, number and weight of marketable unhusked ears, and number of marketable husked ears. Cultivar AG 510 showed a better response than cultivar Centralmex to planting density increases, in relation to characteristics used to evaluate green corn yield. The cultivars did not differ with respect to ear length, stalk diameter, and root system biomass, but cultivar Centralmex showed larger plants and tassels and greater ear height.

\section{REFERENCES}

BANGARWAAS; KAIRON MS; MOR BS. 1993. Effect of plant density and levels of nitrogen on the growth analysis of winter maize (Zea mays L.). Crop Research 6: 5-16.

BAVEC F; BAVEC M. 2002. Effect of plant population on leaf area index, cob characteristics, and grain yield of early maturing maize cultivars (FAO 100-400). European Journal of Agronomy 16: 151-159.
BONDAVALLI B; COLYER D; KROTH EM. 1970. Effects of weather, nitrogen, and population on corn yield response. Agronomy Journal 62: 669-672.

BORRAS L; MADDONI GA; OTEGUI ME. 2003. Leaf senescence in maize hybrids: plant population, row spacing and kernel set effects. Field Crop Research 82: 13-26.

CARDWELL VB. 1992. Fifty years of Minnesota corn production: sources of yield increase. Agronomy Journal 74: 984-995.

CESCONETTO AO; FAVERO S; LAURA VA. 2002. Produção de minimilho com e sem pendão floral em diferentes densidades de semeadura, em Campo Grande (MS). Horticultura Brasileira 20: 330. (Suplemento I).

CHANDRA D; GAUTAN RC.1997. Performance of maize varieties at varying plant densities. Annals of Agricultural Research 18: 375-376.

HOLMES MG; SMITH H. 1977. The function of phytochrome in the natural environment. II. The influence of vegetation canopies on the spectra energy distribution of natural daylight. Photochemical and Photobiology 25: 239-245.

JANDEL. 1992. Jandel TBLCURVE. Table Curve 3.0. Curve fitting software. Corte Madera, Jandel Scientific.

MADDONI GA; OTEGUI ME. 2004. Intraspecific competition in maize: early establishment of hierarchies among plants affects final kernel set. Field Crops Research 85: 1-13.

MADDONI GA; OTEGUI ME; ANDRIEU B; CHELLE M; CASAL JJ. 2002. Maize leaves turn away from neighbors. Plant Physiology 130: 1181-1189.

MAGALHÃES PC; GAMA EEG; MAGNAVACA R. 1993. Efeito de diferentes tipos de despendoamento no comportamento e produção de alguns genótipos de milho. Sete Lagoas: EMBRAPA/CNPMS. 4 p. (Pesquisa em andamento, 12).

MEROTTO JÚNIOR A; ALMEIDA ML; FUCHS O. 1997. Aumento no rendimento de grãos de milho através do aumento da população de plantas. Ciência Rural 27: 549-554.

PATERNIANI E; ZINSLY JR; MIRANDA FILHO JB. 1977. Populações melhoradas de milho obtidas pelo Instituto de Genética. $R e$ latório Científico do Departamento de Genética da ESALQ 11: 108-114.

SAEG. 1997. Sistemas para análises estatísticas, 7.0. Viçosa: Fundação Arthur Bernardes, UFV/DBG.

SANGOI L; GRACIETTI MA; RAMPAZZO C; BIANCHETTI P. 2002. Response of Brazilian maize hybrids from different ears to changes in plant density. Field Crops Research 79: 39-51.

SILVA ACT; ZÁRATE NAH; VIEIRA MC. 2002. Fontes de zinco e populações de plantas na produção de milho-doce. Horticultura Brasileira 20: 330. (Suplemento I).

SILVA PSL; OLIVEIRA FHT; SILVA PIB. 2003. Efeitos da aplicação de doses de nitrogênio e densidades de plantio sobre os rendimentos de espigas verdes e de grãos de milho. Horticultura Brasileira 21: 454-457.

THOMAS PEL; ALLISON JCS. 1975. Competition between maize and Rottboellia exaltata. Journal of Agricultural Science 84: 305-312.

WIDDICOMBE WD; THELEN KD. 2002. Row width and plant density effects on corn grain production in the Northern corn belt. Agronomy Journal 94: 1020-1023. 